\title{
Perception of the Farmers towards Technical Capability of Public Extension Personnel in Middle Gujarat
}

\author{
Subhash Chand $^{1^{*}}$ and A. P. Shukla ${ }^{2}$ \\ ${ }^{1}$ Extension Education, Department of Extension Edu. BACA, AAU, Anand, Gujarat, India \\ ${ }^{2}$ Sardar Patel Agricultural Educational Museum, DoEE, Anand Agricultural University, \\ Anand, Gujarat, India \\ *Corresponding author
}

\section{A B S T R A C T}

K e y w o r d s
Public extension,
Perception,
Technical
capability, Public
private partnership

\section{Keywords}

Public extension, Perception,

Technical capability, Public

\section{Article Info}

Accepted:

10 December 2020
India is mostly a farming nation and about 60-70\% of its population depends directly or indirectly on agriculture. The agriculture extension system in country plays pivotal role in the agriculture development and public extension system has a major role to play. Agriculture Development in India mostly depends on effectiveness of Public agriculture extension, its approaches, service delivery, methodology and processes. The extension personnel are expected that they would persuade the farmers in adoption of the innovation or research outcome. They are considered as technical experts in dissemination of the latest farm technology in the farming domain. On this background, purposely a study was conducted in Anand district of Gujarat to find out the perception of the farmers towards the technical capability of public extension personnel in middle Gujarat. Study revealed that Majority of the farmer (65\%) were found in the middle age group, about $(79.16 \%)$ of the farmers were found in medium level of farming experience, about $(92.50 \%)$ had medium level of extension participation, about $(79.16 \%)$ has medium level of economic motivation, about $(72.50 \%)$ of the farmers has medium level of risk orientation, nearly $(46.66 \%)$ of the farmer has medium level of perception. The independent variables like, education, training received, reading habit, land holding, annual income, extension participation, mass media exposure, economic motivation, risk orientation and innovativeness has positive and highly significant correlation with perception of the farmers towards technical capability of extension personnel. Most of the farmers had favorable opinion about public private partnership in delivering agriculture extension services.

\section{Introduction}

Public Extension plays an important role in the Indian agriculture system. Agriculture development in India mostly depends on effectiveness of the public extension, its approaches, service delivery, methodology and processes. The extension becomes most important link between small technology generating system and big client base. But when we go across extension/ research linkages generally, extension/ research linkages occur in the following sequence. The scientist identifies the research problem and 
research is conducted and reported upon; extension worker read the research report, attend a meeting where the research is reported, or receive it in summarized form; extension personnel pass the finding of the technology to the farmer.

The processes create difficulties and give rise to several questions like usefulness to the farmers, report reaching the extension workers, transferring technology without demonstration etc. it may not be possible to provide research findings effectively to users in a supportive and integrated way.

The rapport and confidence of the farmers on the extension personnel providing these research findings to them is another point of consideration. Often the grass root level extension personnel are considered less useful by the farmers regarding the transfer of technology related to modern and profitable agriculture and aids in better planning of extension linkages in agriculture and allied fields (Sulaiman and Hall, 2002).

In Gujarat agriculture extension programmes imparts new technology to farmers for helping to cultivate, rice, wheat, jowar, bajra, maize, tur, gram, groundnut, cotton, tobacco etc. The major work force of the public extension functionaries is from Gujarat state department of agriculture. Extension education institute EEI (Anand) is the one of the premier institutes for imparting training to extension personnel $\&$ it caters to the need of western Zone states viz., Gujarat, Chhattisgarh, Maharashtra, Rajasthan, Madhya Pradesh, Goa, UT of Dadar Haveli, Diu and Daman.

Based on the above background it is necessary to collect the perception of the farmers towards technical capability of the public extension personnel in Middle Gujarat.

For this purpose, the study was conducted in the Anand District of Gujarat State (India) with following objectives include to ascertain the perception of the farmers towards the technical capability of public extension personnel. To study the relationship between profile of the farmers and their perception towards the technical capability of the public extension personnel. To assess the opinion of the farmers about public-private partnership in delivering agricultural extension services.

\section{Materials and Methods}

The present study was conducted in Anand district of Gujarat state which is bounded on north by Kheda district and south by Vadodara District on east by Panchamahals district and on west by Ahmadabad district. Anand district is composed of 8 talukas. From which two talukas viz., Anand and Borsad having maximum number of progressive/innovative farmers and growing cash crop for the study were selected for the study. A list of villages was obtained from office of Assistant Director of Agriculture, Anand. Out of these villages five village of each taluka consisting more area under cultivation of cash crops or other remunerative crops were selected for the study. A list of farmers from each selected village was obtained from concerned village level workers/panchayat office. Out of these, 12 farmers were selected randomly for this study purpose. The whole of 120 farmers sample were considered as respondents.

Ten villages of Anand and Borsad talukas of Anand district. 12 farmers from each village were randomly selected consisting a sample of 120 farmers. For measurement of age, education, training received, reading habit, farming experience, land holding, annual income, extension participation and mass media exposure structure schedule were developed and used. For measuring economic motivation scale developed by Supe (1969), for risk orientation scale developed by Patel 
and Chauhan (2009), for innovativeness scale developed by Singh (1977) and for measuring perception scale developed by Karunashree (2009) were used with due modification. The data were collected with the help of well structured, pre-tested, Gujarati version interview schedule through personal contact and data were compiled, tabulated and analyzed with the help of various statistical tools to test the hypothesis. The statistical tools such as percentage, mean score, standard deviation and coefficient of correlation were used.

\section{Results and Discussion}

Perception of the Farmers towards the Technical Capability of the Public Extension Personnel

Perception is the degree to which an individual organizes and interpret his sensory impression in order to give meaning to another environment. In this study perception of the farmers towards technical capability of public extension personnel means the feeling of the farmers towards technical capability of public extension personnel. Because agriculture development in India mostly depends on effectiveness of the public agriculture extension, its approaches, service delivery, methodology and processes. The data regarding perception shown in Table 1.

It is clear from table 1 that majority of the farmers (46.66 per cent) had medium level of perception regarding technical capability of extension personnel, whereas by 28.34 per cent and 25.00 per cent of farmers had low and high level of perception, respectively.

It can be concluded that nearly fifty percent of the farmers had medium level of perception. Secondary education level, good extension contact, mass media exposure of the farmer might be the probable reason for medium perception of the farmers. These findings are in line with the results reported by Kulkarni (1998), Rao and Dubey (2001) and Sawant (2001).

Relationship between Characteristics of the Farmers and their Perception towards Technical Capability of Public Extension Personnel

The data presented in Table 2 shows that the independent variables like, education, training received, reading habit, land holding, annual income, extension participation, mass media exposure, economic motivation, risk orientation and innovativeness had positive and highly significant correlation with perception of farmers towards technical capability of extension personnel while the variable like age and farming experience had shown negative and non-significant relationship with perception of the farmers towards technical capability of extension personnel.

It can be inferred that there is no influence of farming experience on perception of farmers towards technical capability of public extension personnel. The probable reason could be that the medium to high experience leads the farmers to avoid risk of new technology and age is directly related with experience and dominancy of other situational and environmental factors complied the experience with recessive in decision making process. The actual participation of the farmers in various extension activities might have made them to interact with extension personnel and progressive farmers who also participated the activities such as, demonstration, meeting, training and the field day etc. which made them enable to see new and recommended technology in natural setting and also helped to learn and practice the skill might be the possible explanation for this result. 
Table.1 Distribution of the farmers according to their perception towards technical capability of public extension personnel $n=120$

\begin{tabular}{|l|l|l|l|}
\hline Sr. No. & Level of perception & Number & Percent \\
\hline 1. & Low perception (below 28.65 score) & 34 & 28.34 \\
\hline 2. & $\begin{array}{l}\text { Medium perception } \\
\text { (between 28.65 to 55.93 score) }\end{array}$ & $\mathbf{5 6}$ & $\mathbf{4 6 . 6 6}$ \\
\hline 3. & High perception (above 55.93 score) & 30 & 25.00 \\
\hline Total & & 120 & 100.00 \\
\hline
\end{tabular}

Mean $=42.29$ S.D. $=13.64$

Table.2 Relationship between the characteristics of the farmers and their perception towards technical capability of public extension personnel $\mathrm{N}=120$

\begin{tabular}{|l|l|c|}
\hline Sr. No. & Independent Variables & Correlation-Coefficient ('r' value) \\
\hline A. & Socio-personal characteristics & $-0.09279(\mathrm{NS})$ \\
\hline 1 & Age & $0.2418^{* *}$ \\
\hline 2 & Education & $0.2547^{* *}$ \\
\hline 3 & Training received & $0.1893^{*}$ \\
\hline 4 & Reading habit & $-0.1659(\mathrm{NS})$ \\
\hline 5 & Farming experience & \\
\hline B. & Economic characteristics & $0.2563^{* *}$ \\
\hline 6 & Land holding & $0.2820^{* *}$ \\
\hline 7 & Annual income & \\
\hline C. & Communication Characteristics & $0.2266^{*}$ \\
\hline 8 & Extension participation & $0.2635^{* *}$ \\
\hline 9 & Mass media exposure & \\
\hline D. & Psychological Characteristics & $0.3069^{* *}$ \\
\hline 10 & Economic motivation & $0.3001^{* *}$ \\
\hline 11 & Risk orientation & $0.2652^{* *}$ \\
\hline 12 & Innovativeness & \\
\hline
\end{tabular}

$\mathrm{NS}=$ non-significant at 0.05 level; $*=$ significant at 0.05 level; $* *=$ significant at 0.01 level

Table.3 Opinion of farmers about public-private partnership $\mathrm{N}=120$

\begin{tabular}{|l|l|l|l|}
\hline Sr. No. & Categories & Number & Percent \\
\hline $\mathbf{1}$ & Unfavorable opinion (below 36.88 score) & 22 & 18.34 \\
\hline $\mathbf{2}$ & Favorable opinion & 72 & 60.00 \\
\hline $\mathbf{3}$ & Highly favorable opinion & 26 & 21.66 \\
\hline Total & & 120 & 100.00 \\
\hline
\end{tabular}

Mean $=44.05 \quad \mathrm{SD}=7.17$

The conclusion emerged out from above finding indicates that innovativeness offers an impetus working for excellence which would enable an individual to manifest this excellence in his field of activities resulting into developing positive perception of the farmers. The study is in concurrence with the findings of Saiyad (2000), Sawant et al., (2001), Chavda (2005) and Beghari et al., (2008). 
Opinion of the Farmers about PublicPrivate Partnership in Delivering Agricultural Extension Services

Public-Private Partnership is operationalized as the collaborative effort between the public and private sectors as per need contributing to one or more stages in the process of production, extension activities, procurement, processing and marketing etc. The opinion of the farmers about this partnership in represented in Table 3 .

It is clear from the table 3 that three-fifth of the farmers (60.00 per cent) had favorable opinion regarding public private partnership followed by 21.66 per cent and 18.34 per cent of the farmer has highly favorable and unfavorable opinion respectively. It can be inferred that majority of the farmers had favorable opinion regarding public private partnership in delivering agricultural extension services. The probable reason might be the good education level, good extension contacts, mass media exposure of the farmers and also farmer might have thought that collaborative approach of both public and private extension services. This finding is in line with the findings of Mande et al., (2010).

It can be concluded from the study that majority of the farmers ( 46.66 per cent) had medium level of perception regarding technical capability of extension personnel. The independent variables like, education, training received, reading habit, land holding, annual income, extension participation, mass media exposure, economic motivation, risk orientation and innovativeness had positive and highly significant correlation while the variable like age and farming experience had shown negative and non-significant relationship with perception of the farmers towards technical capability of extension personnel.

\section{References}

Beghari, A., Fami, S. Rezvanfar, A. and Yazdani, S. (2008). Perception of paddy farmers towards sustainable agriculture technologies. American J. Appl. Sci., 5(10): 1384-1391.

Chavda, V. (2005). Farmers' perception about usefulness of agricultural extension system. Ph.D. thesis (Unpub.), JAU, Junagarh.

Karunashree, E. (2009). Scope of public private partnership in agricultural extension delivery system in Andhra Pradesh. M.Sc. thesis (Unpub.), Yaswant Rao Chavan Open University, Nashik.

Kulkarni, R.R. (1998). Perception of drudgery by farm women. Maharashtra J. Ext. Edu., 17: 288-290.

Mande, J.V., Ankush, G.S. and Suradkar, D.D. (2010). Opinion of the farmers about public extension services. Agric. Sci. Digest, 30(3): 163-167.

Patel, M.C. and Chauhan, N.B. (2009). Entrepreneurial attitude of youth. Agric. Sci. Digest, 29(3): 212-214.

Rao, M.S. and Dubey, V.K. (2001). Managing agricultural production by minimizing environmental risk: A study of farmers perception of environmental risk in pesticide use. Manage Ext. Res. Review, pp 70-77.

Saiyad, A.S. (2000). A study on role perception and role performance of women sarpanch of gram panchayat in Anand district of Gujarat state. Ph.D. thesis (Unpub.), AAU, Anand, Gujarat.

Sawant, A.G., Suryawanshi, S.K. and Bhairamkar, M.S. (2001). Perception of fertilizer user about fertilizer distribution network. J. Maharashtra Agric. Univ., 26(1): 100-102.

Sawant, R.P. (2001). Perception of farmers and extension personal about usefulness 
of existing extension system. Ph.D. thesis (Unpub.), GAU Sardarkrushinagar.

Singh, K. (1977). A study of neo marginal farmers and socio-economic impact of new agricultural technology. Ph.D. thesis (Unpub.), IARI, New Delhi.

Sulaiman, V.R. and Hall, A. (2002). Beyond technology dissemination: reinventing agricultural extension. Outlook on Agric., 31(4): 225-233.

Supe, S.V. (1969). Factor related to difference of rationality in decision making among farmers. Ph.D. thesis (Unpub.), IARI, New Delhi.

\section{How to cite this article:}

Subhash Chand and Shukla, A. P. 2020. Perception of the Farmers towards Technical Capability of Public Extension Personnel in Middle Gujarat. Int.J.Curr.Microbiol.App.Sci. 9(12): 3010-3015. doi: https://doi.org/10.20546/ijcmas.2020.912.356 